Boom juridisch

Postbus 85576

2508 CG Den Haag

T (070) 3307033

E info@bju.nl

www.boomjuridisch.nl

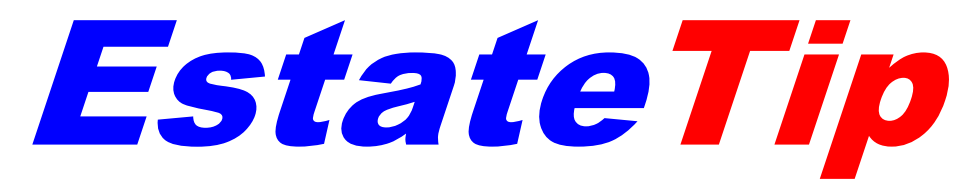

Afl. 2020-10

25 maart 2020

\title{
De erfrechtelijke vorm ontbreekt: toch rechtsgevolgen?
}

\section{'De meest haalbare vorm van zekerheid en de redelijkheid en billijkheid'}

\begin{abstract}
Het zijn bijzondere tijden voor iedereen. Ook erfrechtelijk bezien zitten we in een situatie van social distancing en dat leidt ertoe dat het passeren van een testament - in gewone omstandigheden de normaalste zaak van de wereld - opeens vragen oproept. De KNB, misschien wel het notariële RIVM, liet al van zich horen en ziet ruimte binnen de wettelijke kaders om 'digitale en audiovisuele middelen' in te zetten in het testeertraject.

In een bericht van 22 maart 2020 luidt het als volgt

(https://www.knb.nl/nieuwsberichten/knb-digitale-en-audiovisuele-middelen-toegestaan-bijcoronapatienten):
\end{abstract}

'KNB: digitale en audiovisuele middelen toegestaan bij coronapatiënten De Koninklijke Notariële Beroepsorganisatie (KNB) vindt dat notarissen digitale en audiovisuele middelen moeten kunnen gebruiken om coronapatiënten in staat te stellen een testament te maken. De wet biedt notarissen bij hoge uitzondering de mogelijkheid, mits zij in hun dossier goed verantwoorden waarom zij dat hebben gedaan. De KNB vindt, net als de Vereniging van Estate Planners in het Notariaat (EPN), het juridisch-dogmatisch beter als de wet hiervoor meer mogelijkheden biedt, maar de KNB sluit die binnen de bestaande wettelijke mogelijkheden niet per definitie uit. $\mathrm{Zij}$ is van mening dat notarissen een belangrijke maatschappelijke rol vervullen in het rechtsverkeer en in voorkomende gevallen, zoals deze de plicht hebben mensen te helpen. Dit geldt des te meer in een noodsituatie waarmee Nederland en dus ook het notariaat zich geconfronteerd weet. Dat de geldigheid van testamenten achteraf ter discussie gesteld kan worden bij de rechter, doet daar niets aan af, zo vindt de KNB. De beroepsorganisatie stelt dat het beter is dat notarissen achteraf het verwijt krijgen dat ze iets gedaan hebben, dan dat hen verweten wordt niets gedaan te hebben. De KNB zal notarissen tegen wie in de toekomst mogelijk een dergelijke rechtszaak wordt aangespannen, daarom voluit steunen.'

De EPN pleit evenwel voor een wettelijke voorziening. Uit hun bericht op de website (https://epn-notaris.nl/blog/skypetestament-als-tijdelijke-oplossing-in-noodgevallen/) citeer ik het volgende: 


\section{'Standpunt van de EPN}

Het bestuur van de EPN is van mening dat de wet (Boek 4 Burgerlijk Wetboek en de Wet op het notarisambt) op dit moment niet de mogelijkheid biedt om een testament via Skype te passeren. Een dergelijk testament mist authenticiteit en is, alle goede bedoelingen ten spijt, niet geldig.'

Niemand zal tegen een concrete wettelijke regeling zijn, maar dit staat los van de vraag of 1) de digitale/audiovisuele passeerwijze inderdaad in te passen is dan wel te wringen is in het wettelijk systeem, en

2) of, als er sprake zou zijn van ongeldigheid, dit dan ook betekent dat er geen rechtsgevolgen kunnen worden toegekend aan het notariële 'gebeuren ter zake des doods'.

Vraag 1 laat ik nu rusten en ik wijs op de gedachtegang van de KNB en ook op de vandaag verschijnende AdvoTip 2020-5, 'Besmettelijke ziekten, heldenberoepen en noodtestamenten', van broer Bernard. Deze AdvoTip vindt u hier.

Wel aandacht voor vraag 2.

De zaak die speelde bij Hof Den Haag 6 augustus 2019, ECLI:NL:GHDHA:2019:2800, is dan interessant. Aan de orde was de status van een door een notaris na een gesprek met cliënt opgesteld concepttestament dat niet werd gepasseerd door het overlijden van de aspirant testateur. Het hof is - zo vertaal ik vrij - van mening dat met het concepttestament slechts de wil van erflater vaststaat op het moment van het opstellen van het concepttestament. Maar daarmee is nog niet gegeven:

'dat ook op het moment dat de akte daadwerkelijk zou zijn gepasseerd - en daarmee in dit geval laatstelijk kort vóór het moment van overlijden van erflater - de wil van erflater nog steeds zou luiden overeenkomstig hetgeen is vastgelegd in het concept-testament'.

Het hof overweegt voorts:

'Het toetsingsmoment daarvoor met toepassing van de in de wet geregelde waarborgen is nu juist het verlijden van de notariële akte. Op dat moment zou de notaris alleen met [erflater] zijn geweest, in tegenstelling tot de eerdere gesprekken van de notaris met [erflater] waar steeds [de man] bij aanwezig was. Er kunnen allerlei redenen zijn geweest op grond waarvan [erflater] zijn laatste wil nog zou hebben willen veranderen. Naar het oordeel van het hof is niet boven iedere twijfel verheven dat het concept overeenkomstig de wil van [erflater] is opgemaakt. Blijkens de brief van de notaris van 6 juli 2015 lukte het hem kennelijk niet in het telefoongesprek met [erflater] op 2 april 2015 duidelijkheid te krijgen omtrent de wil van [erflater] . Naar het oordeel van het hof is er geen volstrekte zekerheid dat hetgeen is vastgelegd in het concept-testament overeenstemt met de uiterste wil van [erflater] op het moment van diens overlijden. De door [de man] aangevoerde omstandigheden met betrekking tot de hechte vriendschap tussen hem en [erflater] en het ontbreken van iedere band tussen [de dochter] en [erflater] kunnen - wat daar ook van zij - niet tot een ander oordeel leiden.

In casu ziet het hof geen grond om te oordelen dat het naar maatstaven van redelijkheid en billijkheid onaanvaardbaar is dat de versterferfgenaam zich op het wettelijk versterferfrecht kan beroepen. Maar het beroep op het versterferfrecht zou dus blijkbaar wel naar maatstaven van redelijkheid onaanvaardbaar kunnen zijn! In een nog te 
verschijnen bijdrage van Notamail Verklaard bij SDU-uitgevers schreef ik dat een concepttestament derhalve wel degelijk impact kan hebben:

'Het hangt naar mijn mening af van de omstandigheden van het geval. Ik noem, bijvoorbeeld, het tijdstip tussen het opmaken van het concept en het overlijden, of de omstandigheid dat de notaris de erflater onder vier ogen heeft gesproken. Ook lijkt van belang of de passeerafspraak is gemaakt en men richting de notaris positief gereageerd heeft op het concept. Maar wat men hier ook van vindt, dat de redelijkheid en billijkheid voet aan de grond heeft in het erfrecht staat mijns inziens buiten kijf en blijkt ook hier.'

Toen ik dit schreef, dacht ik vanzelfsprekend nog niet aan Corona. In een geval waarin een door een notaris - na de cliënt 'digitaal en audiovisueel' gesproken te hebben - opgemaakt concepttestament door de cliënt 'digitaal en audiovisueel' bevestigd wordt, zijn de omstandigheden anders dan in het door het hof 'berechte' geval. Men zal dan - met de huidige stand van de techniek - misschien zelfs kunnen spreken van 'volstrekte zekerheid', in ieder geval van een grote mate van zekerheid en in situaties van nood wat mij betreft kunnen constateren dat sprake is van ' $d e$ meest haalbare vorm van zekerheid'.

In een dergelijk geval heeft deze 'handelwijze ter zake des doods' rechtsgevolg, in die zin dat het naar maatstaven van redelijkheid en billijkheid onaanvaardbaar is dat versterferfgenamen en testamentaire erfgenamen zich beroepen op het ontbreken van (eventuele) vormvoorschriften en op hun (vermeende) erfrechtelijke strepen gaan staan. De omstandigheid dat de notaris betrokken is, het coronavirus woedt en het belang van de testateur, noopt tot deze conclusie. Rechtspositivisme moet zeker in deze tijden vermeden worden.

Ter voorkoming van misverstanden: ik ga ervan uit dat de notaris op dezelfde wijze 'als gebruikelijk' naar vermogen toetst of de betrokkene zijn of haar wil kan bepalen en de handelwijze keurig documenteert, zodat sprake is van een level playing field voor de belanghebbenden indien hierover discussie bestaat. Vergelijk Hof Amsterdam 16 december 2014, ECLI:NL:GHAMS:2014:5353. Dit zou bij een nieuw wettelijk regime niet anders zijn.

In de zojuist bij Kluwer verschenen zevende druk van het Handboek Erfrecht (Van Mourik c.s.), VII. 4.1, schreef ik nog het volgende over de vormvoorschriften, zij het in de sfeer van de uitleg van de uiterste wil:

'Het belang dat de uiterste wilsbeschikking zo wordt uitgevoerd als de testateur gewild heeft, acht ik groter dan de bescherming van vormvoorschriften. Deze vormvoorschriften zijn bovendien (met name) gesteld in het belang van de testateur. Als er goede aanknopingspunten zijn om de wil van erflater vast te stellen anders dan op het eerste gezicht in de uiterste wil lijkt te staan, dan moet die kans met beide handen worden aangegrepen.'

U snapt dat ik ook zo denk over het zorgvuldige (wellicht niet helemaal conform de vormvoorschriften) tot stand gekomen 'digitale/audiovisuele-testament'.

Ik mag in dit verband graag nog verwijzen naar de prachtige boekbespreking van E. Korthals Altes, 'Boekbespreking, De wereld van J.B.M. Vranken, een vervolg', WPNR 2005/6643 die het even mooie boek bespreekt van Vranken in de Asser-serie.

Een enkel citaat waarmee ik de auteur tekort doe: 
'Waarom zou men dit probleem niet kunnen oplossen door gevallen waarin met voldoende mate van zekerheid en nauwkeurigheid kan worden vastgesteld wat de erflater kort voor zijn dood wilde dat na zijn dood zou geschieden, op één lijn te stellen met de situatie dat de laatste wil van de erflater wél in een nieuw testament is vastgelegd? In dat geval is, zo kan men ook zeggen, toepassing van de op rechtszekerheid steunende regels van de art. 4:42 en 4:94 BW naar maatstaven En: van redelijkheid en billijkheid niet aanvaardbaar.'

'In de praktijk zal dat neerkomen op situaties waarin de notaris een voldoende nauwkeurige opdracht heeft ontvangen of zelfs al een concept heeft vervaardigd, maar de voortijdige dood van de erflater het verlijden van de akte verhindert. Nu zullen enthousiaste aanhangers van de rechtszekerheid wel tegenwerpen dat we ons aldus op een hellend vlak begeven, maar dat behoeft mijns inziens niet ertoe te leiden dat we onontkoombaar naar peilloze diepten afglijden. Het komt erop aan of de laatste wil van de erflater met voldoende zekerheid en nauwkeurigheid valt vast te stellen. Zo niet, dan zal de rechtszekerheid moeten prevaleren.'

We zitten op een lijn.

Let op: ik heb mij in deze Tip niet uitgelaten over de vraag of de digitale/audiovisuele passeerwijze te passen/wringen is in het wettelijk systeem. Ik heb ook niet ontkend dat het gemakkelijk zou zijn als we een concrete wettelijke regeling zouden hebben. Ik heb slechts willen zeggen dat het zorgvuldige (wellicht niet helemaal conform de vormvoorschriften) met tussenkomst van de notaris tot stand gekomen 'digitale/audiovisuele-testament' wel degelijk rechtsgevolg heeft.

Tot volgende week!

Prof. mr. dr. F.W.J.M. Schols

ScholsBurgerhartSchols

\section{Boomjuridisch}

www.scholsburgerhartschols.nl www.boomjuridisch.nl

(C) 2020 Boom juridisch | ScholsBurgerhartSchols

Hoewel de uiterste zorg is besteed aan de inhoud van EstateTip Review aanvaarden de uitgever en de redactie geen aansprakelijkheid voor onvolledigheid of onjuistheid. 